\title{
Breeding Strategy of Acacia Hybrid (Acacia mangium $\times$ A. auriculiformis) to Increase Forest Plantation Productivity in Indonesia
}

\author{
Sri Sunarti ${ }^{1 *}$, Mohamad Na'iem², Eko Bhakti Hardiyanto², Sapto Indrioko² \\ ${ }^{1}$ Center for Forest Biotechnology and Tree Improvement J1. Palagan Tentara Pelajar Km. 15. Purwobinangun, Pakem, Sleman, \\ Yogyakarta \\ ${ }^{2}$ Departement of Silviculture, Faculty of Forestry, Gadjah Mada University, Jl. Agro, Sekip, Yogyakarta, Indonesia
}

Received January 22, 2013/Accepted June 11, 2013

\begin{abstract}
Acacia hybrid (Acacia mangium $\times$ A.auriculiformis) shows better growth and wood properties, and tolerance to pest and disease. Currently, acacia hybrid breeding strategy was developed through naturally hybrid selected from trees grown in plantation. However, mass propagation of acacia hybrid using such kind of strategy was not satisfied due to ageing effect. This study was aimed to develop a new acacia hybrid breeding strategy using controlled pollination hybridization technique. The strategy was developed through a series of research: flowering, crossing, hybrid identification, clone multiplication, and clonal test. The results of study showed that the series of research for developing acacia hybrid breeding strategy was achieved. Flowering time synchronization provided a high probability for the success of controlled pollination hybridization. Leaves taxonomy at seedling stage revealed to be an efective way to identify acacia hybrid with acuracy of $92.2 \%$. The acacia hybrid was succesfully propagated using shoot cutting at rate of $78.1 \%$. The best selected clones of acacia hybrid outperformed in height growth at rates of $17.28 \%$ over to superior pure parents, which is equivalent to the estimated stand productivity at around 48 $m^{3} h a^{-1} y^{-1}$. The series of research provided a new effective and efficient breeding strategy for acacia hybrid.
\end{abstract}

Keywords: Acacia auriculiformis, Acacia mangium, acacia hybrid, controlled pollination, breeding strategy

*Correspondence author,email:narti_nirsatmanto@yahoo.com,tel.+62-274-895-954,fax : +62-276-896-080

\section{Introduction}

Acacia hybrid is an out-crossed variety between Acacia mangium and $A$. auriculiformis, either naturally or artificially. Superior acacia hybrid has some merits as compared to the pure parents, such as fast growth, straight main stem, light branches, soft bark, and resistance to pest and disease (Nikles et al. 1998; Kha 2001). In addition, they had better wood properties with higher quality for pulp and paper industry compared to A. mangium (Kim et al. 2009; Khalid et al. 2010; Rukeya et al. 2010; Yahya et al. 2010; Kato et al.2012; Kha et al.2012).

Research and development on acacia hybrids in Indonesia is limited. Although some researches has been done using material selected from natural acacia hybrid tree grown in plantation, the results were less optimal due to the long of time and the low productivity in multiplication due to the ageing effects (Hardiyanto 2004). Therefore, development an effective and efficient breeding strategy to provide optimal results of acacia hybrid is necessary. One of the possibilities to achieve this strategy is through the use of artificial controlled pollination technique.

The purpose of this study was to develop an effective and efficient breeding strategy for acacia hybrid to support a high productive forest plantation. The breeding strategy was established through a series of research activities covering flowering phenology, controlled pollination hybridization, hybrid seed quality, identification and verification of the hybrid, hybrid clone multiplication and hybrid clonal test. The result of respective research was discussed in detail in this paper.

\section{Methods}

Breeding strategy for acacia hybrid Proposed breeding strategy to obtain superior acacia hybrid through artificial control pollination is presented in Figure 1. The breeding strategy was established as an effort to obtain higher probability of hybrid vigor or heterosis and to minimize the less vigor hybrid as well. Some researches involved in this strategy covered flowering phenology, controlled pollination hybridization, hybrid seed quality, identification and verification of hybrid, hybrid clone multiplication and hybrid clonal test.

Flowering phenology The flowering phenology was observed in breeding garden of $A$. mangium and $A$. auriculiformis in Centre for Forest Biotechnology and Tree Improvement (CFBTI), Yogyakarta. The observation was focused to obtain the synchronized of flowering time 


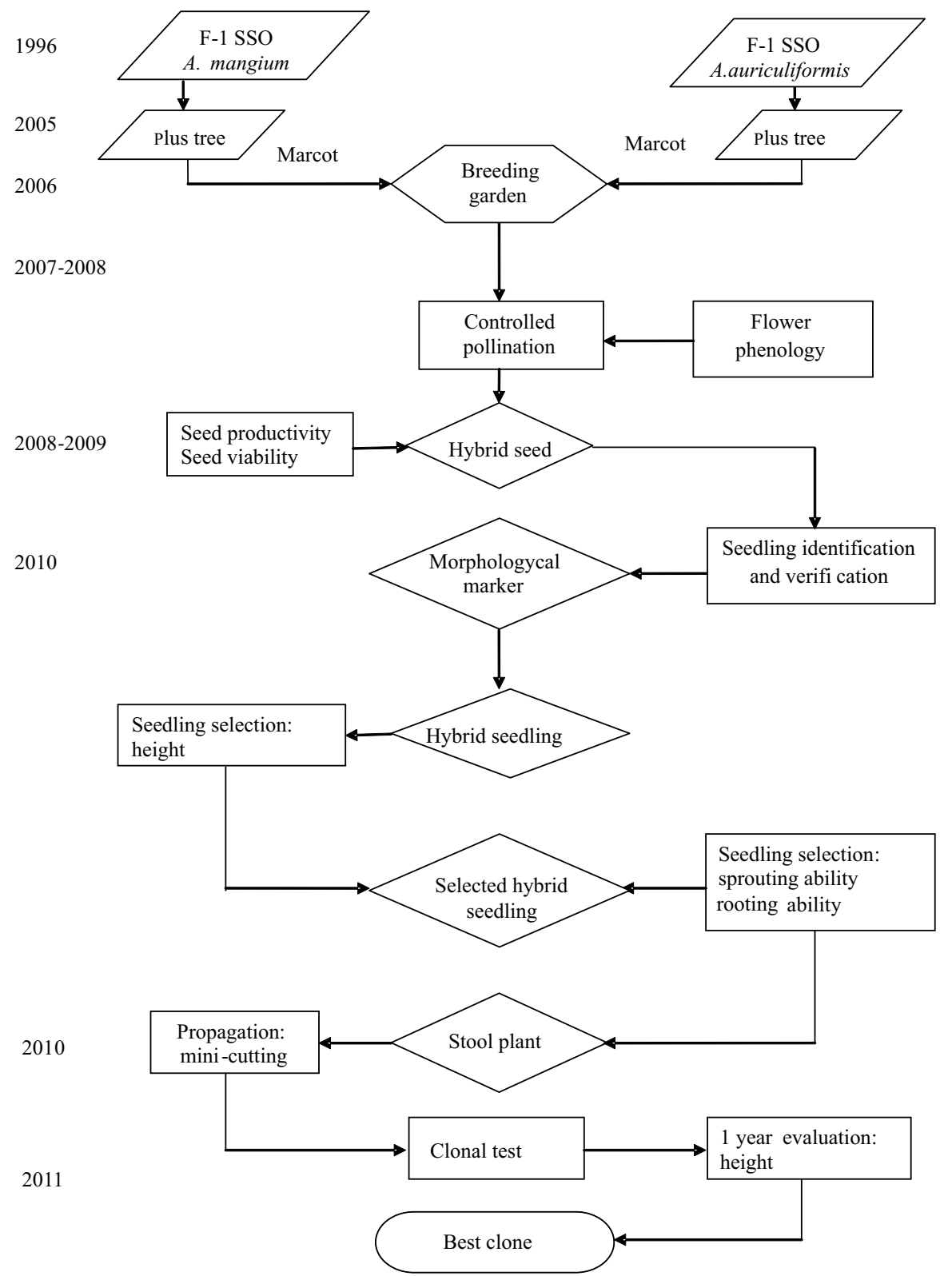

Figure 1 Flow chart of breeding strategy of acacia hybrid (A. mangium $\times$ A. auriculiformis).

between $A$. mangium and $A$. auriculiformis trees. The method of observation is by accessing periodically on every week using scoring system (Ibrahim 1993): score $0=$ no flowering; 1 = small flowering $(<1 / 3$ crown flowered $) ; 2=$ moderate flowering $(1 / 3-2 / 3$ crown flowered); $3=$ heavily flowering $(>2 / 3$ crown flowered).

Controlled pollination hybridization Hybridization was done in breeding garden of $A$. mangium and A. auriculiformis in CFBTI, Yogyakarta. Based on the result of flowering phenology, controlled pollination hybridization was then practiced using another method, in which the crossing between the both parent species was done without emasculation (Sedgley et al. 1991). This method was applied when the both stigma and pollen are in the peak of receptive time. In this study, the receptive time was observed preliminary at around 06:00-10:00 am. The hybridization was done using $A$. mangium as a female (pollen receptor) and $A$. auriculiformis as a male (pollen donor).

Hybrid seed quality The seed quality was observed by calculating the germination rate of the hybrid seed. To increase homogenous of the environment, the seed was germinated aseptically in tissue culture laboratory. The observation of germination was done from the $3^{\text {rd }}$ day up to the $14^{\text {th }}$ day after seed sowing. Seed germinated after the $14^{\text {th }}$ was not included in the germination rate evaluation. The germinant was classified into 2 categories: normal and 
abnormal. Germinant was categorized as normal if it composed of complete organs, such as root (radicle), stem (hypocotyl and epicotyl), and shoot leaves. While it was categorized as abnormal if it composed of not complete organs or not having one or more criteria as the normal organs (Wang 1991). The normal germinant was then pricked out into a poly-bag containing media of top soil for further identification and verification.

Identification and verification of hybrid The hybrid seedling identification was done using morphological markers developed by Gan and Sim (1991) as presented at Figure 2. The seedling that morphologically identified as a hybrid was then verified using molecular markers of SCAR to determine the status of true hybrid (Widyatmoko \& Shiraishi 2003). Identification of hybrid seedling was done at the nursery, while the verification using SCAR markers was done at the molecular laboratory of CFBTI.

Hybrid clone multiplication The seedling verified as true hybrid, hereinafter referred as acacia hybrid, was then selected for further testing based on their growth performance in nursery level at age 4 months and their ability for mass vegetative propagation, such as the sprouting after topping and the rooting after shoots cutting. The selected seedling were then used as stool plants and transferred in clone multiplication area (CMA) for mass propagation. The juvenile shoots collected from the stool plants were used for shoots cutting which was maintained in green house facilitated with a set of misting unit.

Hybrid clonal test Amount of 44 selected seedlings, hereinafter referred as acacia hybrid clone, which was mass propagated through shoot cutting were used as genetic material for field hybrid clonal test to find out the best acacia hybrid clones. The experimental design of clonal test was laid out as Incomplete Block Design with a single tree-plot, 20 replications and spacing of $3 \times 3 \mathrm{~m}$. Out of 44 clones, 4 controls were also involved in the clonal test for comparison. The controls consisted of 2 pure species of $A$. mangium and $A$. auriculformis, in which the each species was propagated using both seedling and cutting. The 4 controls were derived from pure improved seed collected from the best current seed sources: first-generation seedling seed orchard (SSO) of $A$. auriculiformis and second-generation SSO of $A$. mangium. Clonal test was established at Wonogiri, Central Java, $200 \mathrm{~km}$ a part of CFBTI site.

\section{Results and Discussion}

Flowering phenology Results of flowering intensity for $A$. mangium and A. auriculiformis during the year of 20072008 observed in breeding garden are presented in Figure 3, Figure 4, and Figure 5. In 2007, the peak of flowering intensity for A. mangium was observed on December with the rates of around $41.7 \%$, while that in 2008, it was observed on January with the rates of around $68.7 \%$. In case for $A$. auriculiuformis, the peak of flowering intensity in 2007 was observed on September and December with the rates of around $10.0 \%$, while that in 2008 , it was observed in May with the rates of around $66.7 \%$ (Table 1 ).

The flowering time synchronization between $A$. mangium and A.auriculiformis in 2007 was observed in September and December with the average of the rates of $19.8 \%$. In 2008 the flowering time synchronization was observed at January-May with the average of the rates of $28.66 \%$ (Figure 6). Based on these results, the controlled hybridization pollination in 2007 and 2008 were then practiced at such respective synchronized flowering time periods using $A$. mangium as a female parent and $A$.

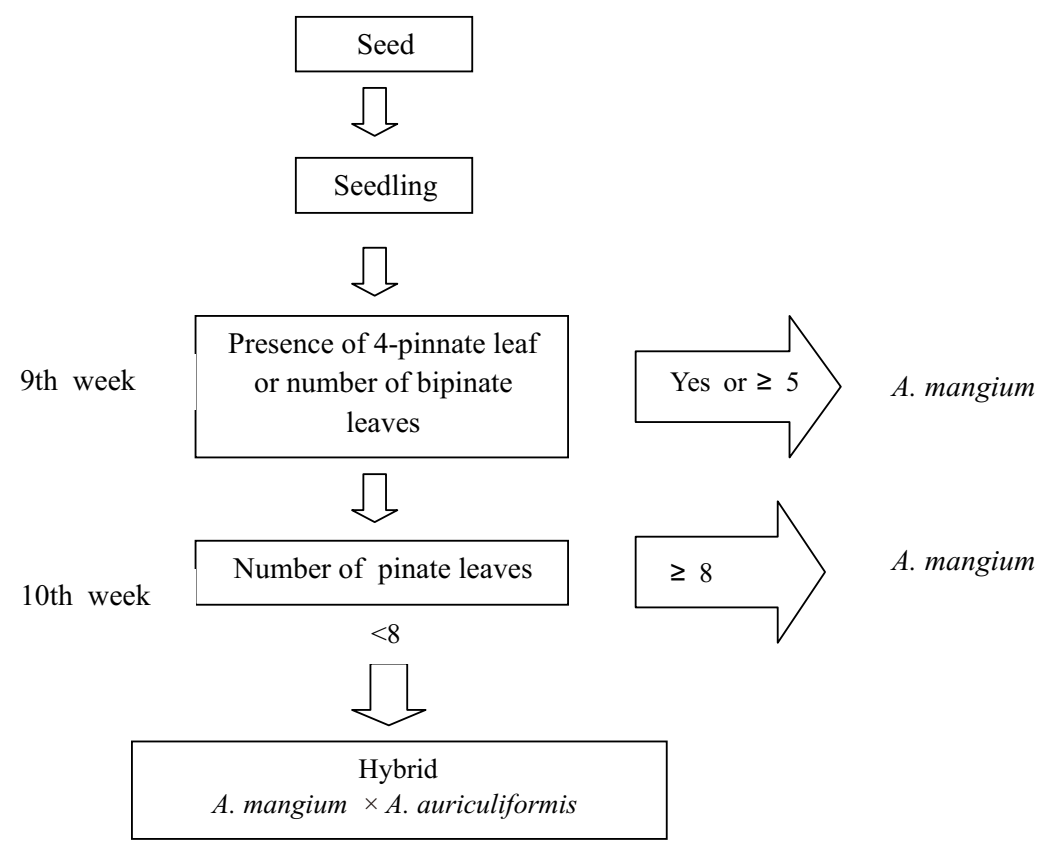

Figure 2 Diagrammatic representation of the simplified method developed by Rufelds (1988) to identify acacia hybrid (A. mangium $\times$ A. auriculiformis). 


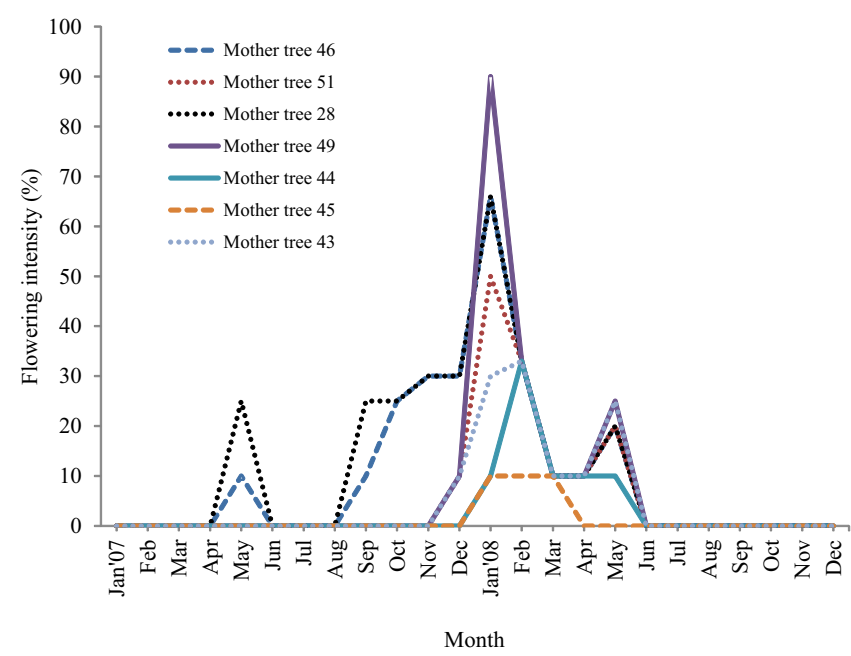

Figure 3 Time and flowering intensity (\%) of A. mangium at breeding garden of CFBTI

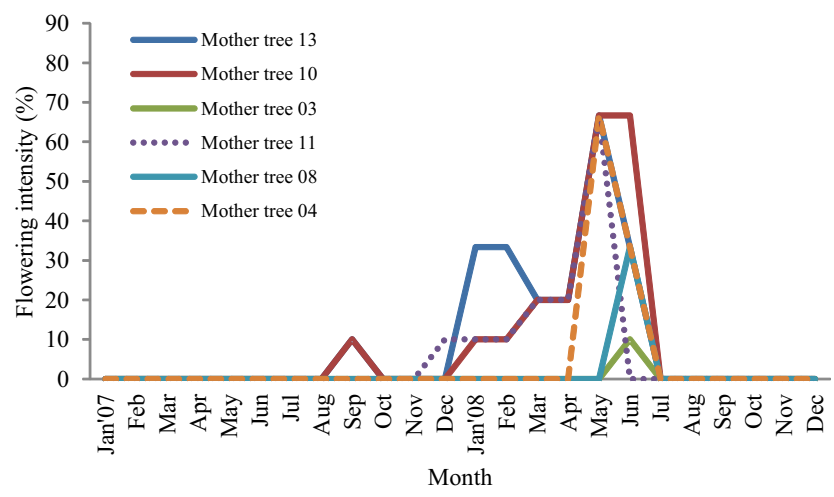

Figure 5 Time and flowering intensity (\%) of $A$. auriculiformis from Papua New Guinea provenance at breeding garden of CFBTI.

auriculformis as a male parent (pollen donor). About 6 and 22 pairs of crossing A. mangium $\times$ A. auriculiformis in 2007 and 2008 have already done respectively.

The lack of the number of flowered trees and the smaller rates of flowering intensity in 2007, either for A. mangium or $A$. auriculiformis, might be due to internal factor of the genetics of tree, such as hormonal system related to the physiological character of the trees (Opick \& Rofle 2005). Regarding to this factor, one of possible reasons is that the tree is not mature enough physiologically to produce flower and reproductive organ. This is because in 2007 the trees inbreeding garden were still young, at 1 year of age. According to Ibrahim (1993), A. mangium starts to first flowering and reproductive phase at 18-20 months of age.

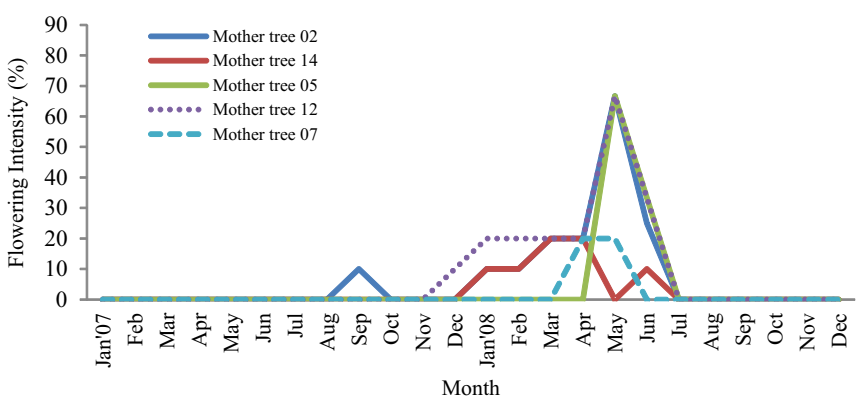

Figure 4 Time and flowering intensity (\%) of $A$. auriculiformis from Australia provenance at breeding garden of CFBTI.

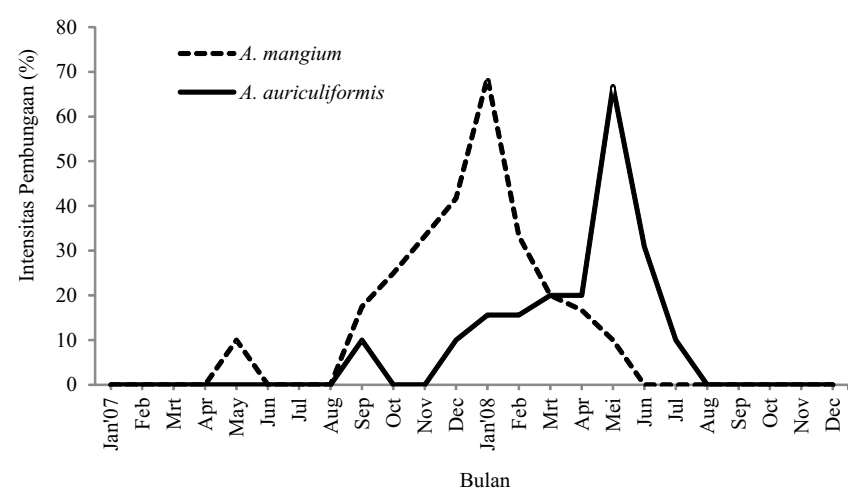

Figure 6 Syncronization of flowering time between $A$. mangium and $A$. auriculiformis at breeding garden of CFBTI in 2007-2008.

This could be verified in the subsequently years where the number of flowered trees increased with the increase of age, either for A. mangium or A. auriculiformis. In 2008, almost all of the trees in breeding garden beared flowers, although with varied flowering intensity. Similar to the differences in number of flowered trees, the varied of flowering intensity might be due to internal factor of the genetics of tree which related to the hormonal, particularly phytohormones that control flowering system (Pallardy 2008).

Controlled pollination hybridization Based on the synchronized flowering time, controlled pollination hybridization between $A$. mangium and $A$. auriculiformis in 2007 provided a total of 6 crossing combinations from 2 
Table 1 Mean of monthly flowering intensity of A.mangium and A. auriculiformis at the breeding garden of CFBTI in 2007-2008

\begin{tabular}{|c|c|c|c|c|}
\hline \multirow{3}{*}{ Month } & \multicolumn{4}{|c|}{ Mean of flowering intensity (\%) } \\
\hline & A.mangium & A. auriculiformis & A.mangium & A. auriculiformis \\
\hline & \multicolumn{2}{|c|}{ Year 2007} & \multicolumn{2}{|c|}{ Year 2008} \\
\hline January & 0 & 0 & 68.7 & 15.6 \\
\hline February & 0 & 0 & 33.3 & 15.6 \\
\hline March & 0 & 0 & 20 & 20 \\
\hline April & 0 & 0 & 16.7 & 20 \\
\hline May & 10 & 0 & 10 & 66.7 \\
\hline June & 0 & 0 & 0 & 30.9 \\
\hline July & 0 & 0 & 0 & 10 \\
\hline August & 0 & 0 & 0 & 0 \\
\hline September & 17.5 & 10 & 0 & 0 \\
\hline October & 25 & 0 & 0 & 0 \\
\hline November & 33.3 & 0 & 0 & 0 \\
\hline December & 41.7 & 10 & 0 & 0 \\
\hline
\end{tabular}

individual trees of A. mangium and 4 of A. auriculformis. While that in 2008, a total of 22 crossing combinations were obtained from 6 individual trees of $A$. mangium and 8 of $A$. auriculformis (Table 2). Amount of 23 out of the total crossing combinations successfully produced pods/fruits containing putative hybrid seed.

The succeeded 23 crossing combinations produced 692 spikes which contained of 3,384 of sound seeds and 1,581 of empty seeds (Table 3 ). The number of spikes and seeds increased with the increasing number of crossing combinations during 2007-2008. The average number of pod per spike in 2007 was 1.9 pods containing the average number of 2 sound seed per pod. The average number of pods and sound seed increased in 2008 at around 4.4 pods with 5.3 sound seed per pod.

During 2007-2008, not all trees in breeding garden, either A. mangium or A. auriculiformis, was flowering yet. As explained in preceding paragraph, the lack of number of flowered trees might be due to the low maturity of the trees. Maturity of woody trees varies among species because the differences of the lenght of juvenile stage. Some conifers remain in the juvenile stage for less than 1 year and other species may more than 1 year (Pallardy 2008).

The increased for A. auriculiformis in 2008 which is at the same time accompanied by the decreased of intensity for A. mangium, might provide a change for storing of the pollen of $A$. auriculiformis. The stored pollen then could be used for controlled pollination hybridization in the next flowering seasons of $A$. mangium, at which the receptive pollen of $A$. auriculiformis was not available yet. However, numerous reports give some information on handling and longevity of pollen storage on breeding program.

The small average number of sound seed from controlled pollination hybridization between $A$. mangium and $A$. auriculformis in breeding garden in this study might be due to the incompatibility between the stigma of female trees and the pollen from male trees (Chaudary 1984). Another possible reason was the differences in receptivity between stigma of $A$. mangium and pollen of $A$. auriculformis which then caused an abnormal flowering process and inhibited producing sound seed. The differences in receptivity are commonly occurred during inter-specific hybridization (Chaudary 1984; Nghiem 2012).

In this study, the direct controlled pollination hybridization (anther method) was basically practiced according to the method proposed by Segley et al. (1991). However a small modification was applied following to the selection of crossing time. The crossing time selection revealed that direct controlled pollination practiced in the morning could increase the average number of sound seed production from 2.8 seeds to be 5.3 seeds or increased $89.3 \%$. The crossing time selection was determined on the basis of the starting flower receptivity, that as in the night when the stigma was receptive, then followed by pollen receptivity soon after when the stigma start to open (Ibrahim 1993).

Hybrid seed quality The sound seed of hybrid obtained from the controlled pollination was germinated and then compared to that of the pure A. mangium. Result of study showed that the average germination rate of hybrid seed was $48.1 \%$, which was lower than that of the pure A. mangium. The $14.43 \%$ of the germinated hybrid seed showed an abnormal performance. In case of pure A. mangium, all germinated seed showed a normal performance (Table 4).

According to Wang (1991), the average viability of hybrid seed in this study $(48.1 \%)$ was categorized as low. This might indicate that incompatibility between stigma of $A$. mangium and pollen of $A$. auriculiformis was occurred, as a commonly observed in the inter-specific hybridization. Incompatibility between stigma and pollen would cause less vigor seed and abnormal seedling. The abnormal performance is also caused by morphological immature embryo of seed and imperfect fertilization process. Seed with matured embryo will produce sound seed which will germinate immediately in suitable condition and grows vigorously.

Identification and verification of hybrid Germinated seed were then transferred in pots for identification of putative hybrid in seedling stage. The 135 of 165 seedlings were identified as acacia hybrid based on morphological markers of 
the leaves development pattern. Subsequently, $92.2 \%$ of the morphological identified hybrid seedling was verified as true acacia hybrid using molecular markers (Figure 7). These results indicated that morphological markers through leaves development pattern could be used to effectively identify an acacia hybrid at seedling stage. The verified true acacia hybrid was then selected based on their growth performance, sprouting and rooting ability for further clone multiplication.

The developed morphological marker which was simplified by Gan and Sim (1991) through leaves development pattern revealed that by using this markers the precision for acacia hybrid identification was higher than that using others markers, such as leaves color, type of pubescence, and number of vein phylodia. Sunarti (2007) by using the later markers reported that the precision of identification of true acacia hybrid ( $A$. mangium $\mathrm{x} A$. auriculiformis) in seedling stage was only $25 \%$. The colour of leaves probably strongly influenced by environment such as temperature and light.

Hybrid clone multiplication There were 53 acacia hybrid seedlings that were selected based on their growth performance. They were then tested for sprouting and rooting ability through topping and shoot cutting. The result showed that after topping and cutting, the average of sprouting and rooting ability were high, that is 16.5 shoots per seedling with $78.4 \%$ of rooting ability.

Analysis of variance showed that the hybrid crossing combinations significantly affected the sprouting and rooting ability of acacia hybrid seedling at confidence level of $95 \%(P<0.05)$. It revealed that sprouting ability of a seedling after topping was influenced by genetic factor, thus indicating a potency of selection to obtain acacia hybrid seedling as stool-plant with high productive of sprouting. High sprouting and rooting ability on stool-plant promised acacia hybrid to be developed on clonal forestry succesfully.

Sprouting ability of acacia hybrid observed from the best 5 hybrid crossing combinations in present study was 14.6 shoots per seedling, which was intermediate between pure A. mangium (5.0 shoots per seedling) and A. auriculiformis (16.6 shoots). This is in agreement with other studies reported by Wong and Haines (1991), Paupard et al. (1994), and Monteuuis (1995) that acacia hybrid showed intermediate between $A$. mangium and A. auriculiformis in sprouting ability. This result was also higher as compared to the previous study reported by Kha (2001) in Vietnam using

Table 2 Crossing combination of $A$. mangium $\times$ A. auriculiformis practiced at breeding garden of CFBTI in 2007-2008

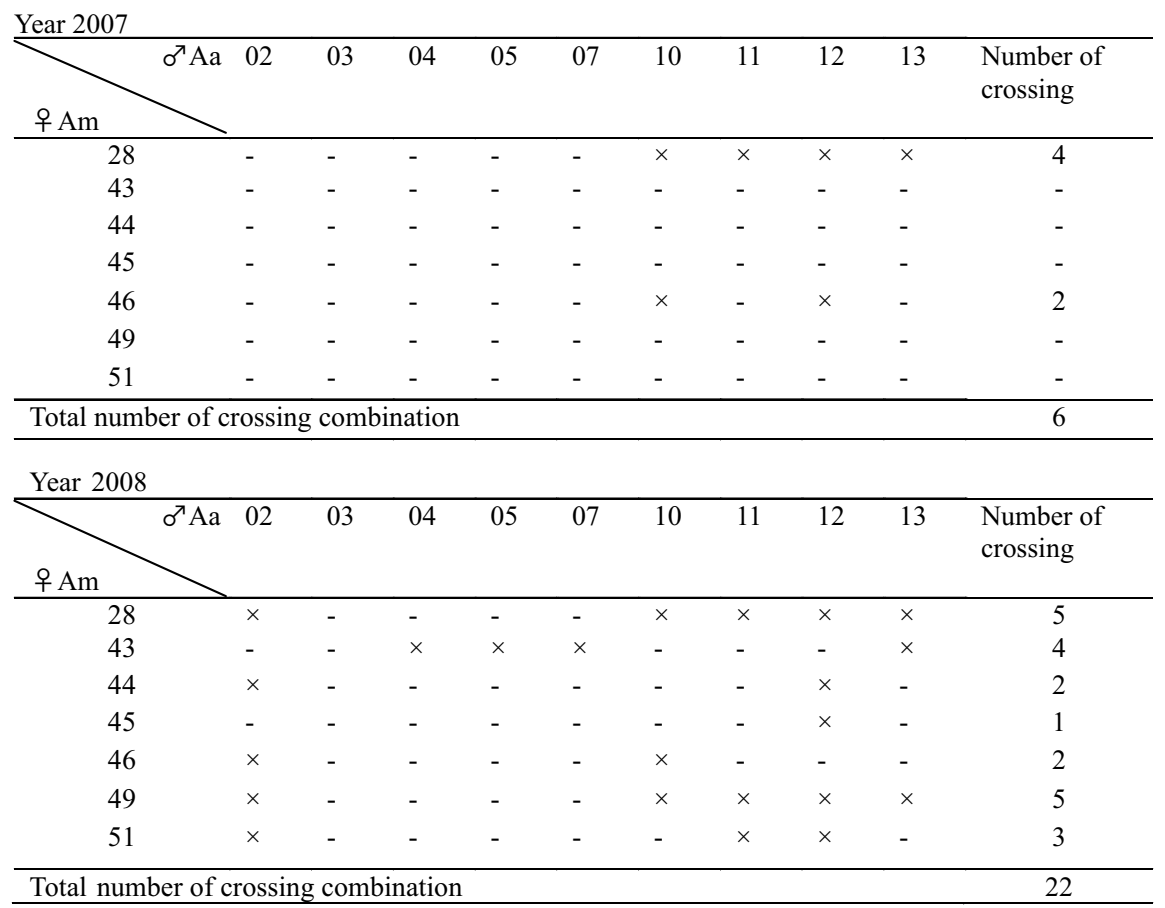

Table 3 Pod and seed production of Acacia hybrid at breeding garden of CFBTI in 2007-2008

\begin{tabular}{|c|c|c|c|c|c|c|c|}
\hline \multirow{3}{*}{ Flowering season } & \multicolumn{7}{|c|}{ Number of } \\
\hline & \multicolumn{2}{|c|}{$\begin{array}{c}\text { Crossing } \\
\text { combination }\end{array}$} & \multirow[t]{2}{*}{ Crossing } & \multirow[t]{2}{*}{ Spike } & \multirow[t]{2}{*}{ Pod } & \multicolumn{2}{|c|}{ Seed } \\
\hline & Succeed & Failed & & & & Sound & Poor \\
\hline Year 2007 & 6 & 0 & 23 & 46 & 86 & 176 & 71 \\
\hline Year 2008 & 17 & 5 & 89 & 137 & 606 & 3.198 & 1.510 \\
\hline Total & & & 112 & 183 & 692 & 3.384 & 1.581 \\
\hline
\end{tabular}




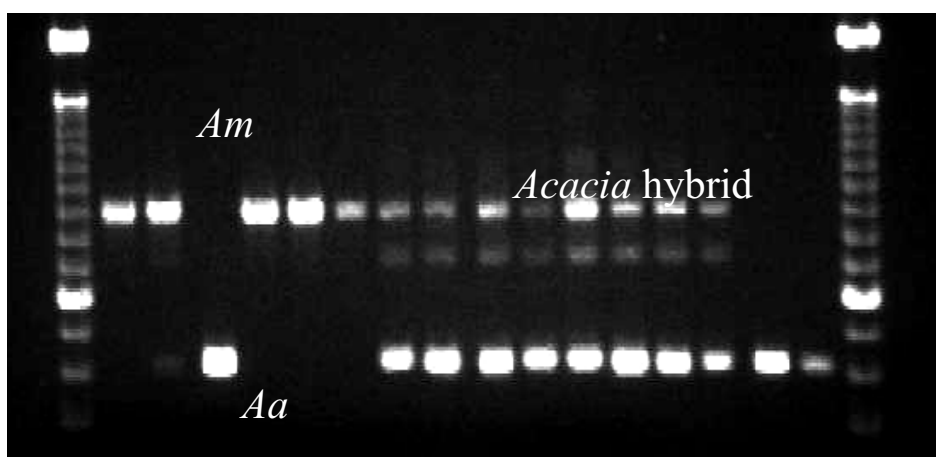

Figure 7 Binding pattern resulted from electrophoresis using agarose $1.2 \%$ with ethidium bromide staining and primer R01.

Table 4 Seed germination of acacia hybrid resulted from controlled pollination hybridization at breeding garden of CFBTI

\begin{tabular}{|c|c|c|c|}
\hline \multirow{2}{*}{$\begin{array}{l}\text { Crossing combination } \\
A m \times A a\end{array}$} & \multicolumn{3}{|c|}{ Mean of germination rate $(\%)$} \\
\hline & $\begin{array}{c}\text { Normal } \\
\text { germinant }\end{array}$ & $\begin{array}{l}\text { Abnormal } \\
\text { germinant }\end{array}$ & Not germinated \\
\hline $28 \times 02$ & 59.1 & 24.2 & 16.7 \\
\hline $46 \times 02$ & 66.3 & 15.0 & 18.8 \\
\hline $46 \times 10$ & 53.8 & 33.8 & 12.5 \\
\hline $45 \times 12$ & 64.3 & 7.1 & 28.6 \\
\hline $49 \times 12$ & 33.3 & 11.8 & 54.9 \\
\hline $49 \times 02$ & 241 & 3.5 & 72.4 \\
\hline $49 \times 10$ & 42.9 & 2.0 & 55.1 \\
\hline $49 \times 13$ & 55.5 & 7.8 & 36.7 \\
\hline $49 \times 11$ & 39.3 & 28.6 & 32.1 \\
\hline $44 \times 02$ & 57.1 & 0 & 42.9 \\
\hline $44 \times 12$ & 33.3 & 25 & 41.7 \\
\hline Mean & 48.1 & 14.4 & 37.5 \\
\hline Control $^{* *}$ & 91.0 & 0.0 & 9.0 \\
\hline
\end{tabular}

Table 5 Height growth superiority of 12 acacia hybrid clones compared to 4 controls of pure species parents

\begin{tabular}{|c|c|c|c|c|c|c|}
\hline Rank & Clone & $\begin{array}{c}\text { Mean } \\
\text { height }(\mathrm{m})\end{array}$ & $\begin{array}{c}\text { Superiority to } \\
\text { control } 1 \\
(\%)\end{array}$ & $\begin{array}{c}\text { Superiority to } \\
\text { control } 2 \\
(\%)\end{array}$ & $\begin{array}{c}\text { Superiority to } \\
\text { control } 3 \\
(\%)\end{array}$ & $\begin{array}{c}\text { Superiority to } \\
\text { control } 4 \\
(\%)\end{array}$ \\
\hline 1 & 44 & 4.48 & 13.71 & 17.28 & 13.13 & 35.35 \\
\hline 2 & 16 & 4.17 & 5.84 & 9.16 & 5.30 & 25.98 \\
\hline 3 & 25 & 4.10 & 4.06 & 7.33 & 3.51 & 23.87 \\
\hline 4 & 38 & 3.88 & -1.50 & 1.57 & -4.04 & 17.22 \\
\hline 5 & 12 & 3.83 & -2.80 & -0.03 & -0.03 & 15.71 \\
\hline 6 & 29 & 3.79 & -2.80 & -1.00 & -0.05 & 14.50 \\
\hline 7 & 42 & 3.70 & -6.10 & -3.00 & -0.07 & 11.78 \\
\hline 8 & 20 & 3.67 & -6.90 & -4.00 & -0.07 & 10.88 \\
\hline 9 & 36 & 3.52 & -10.70 & -8.00 & -0.11 & 6.34 \\
\hline 10 & 40 & 3.45 & -0.12 & -10.00 & -0.13 & 4.23 \\
\hline 11 & 17 & 3.39 & -14.00 & -11.00 & -0.14 & 2.42 \\
\hline 12 & 4 & 3.37 & -14.00 & -12.00 & -0.15 & 1.81 \\
\hline Control 1 ${ }^{\text {a) }}$ & & 3.94 & & & & \\
\hline Control $2^{\text {b) }}$ & & 3.82 & & & & \\
\hline Control $3^{\mathrm{c})}$ & & 3.96 & & & & \\
\hline Control $4^{\mathrm{d})}$ & & 3.31 & & & & \\
\hline
\end{tabular}

a) Clonally propagated seed of $A$. auriculiformis collected in first-generation (F-1) SSO

b) Seedling of $A$. mangium derived from seed collected in second-generation (F-2) SSO

${ }^{c)}$ Clonnaly propagated seed of $A$. mangium collected in second-generation SSO

d) 1 year old of $A$. mangium stand population in F-1 SSO 
1 year old of acacia hybrid which produced 9.7 shoots per seedling.

Hybrid clonal test The survival rate of acacia hybrid in this clonal test was excellent, exceeding $93 \%$ based on the result of 1 year height growth evaluation. While the averages of 4 controls of pure A. mangium and A. auriculiformis was $90 \%$. This result indicated that the tested acacia hybrid clones well adapted in the poor soil condition which is composed of acid ( $\mathrm{pH}$ of 4.9) and clay texture with lack of $\mathrm{N}$ and $\mathrm{P}$.

Height growth of acacia hybrid in the clonal test varied ranging betwen $1.5-4.48 \mathrm{~m}$. Stastistically, height growth between the tested clones were significantly different at confidence level of $95 \%(p<0.05)$. It showed that height growth of the hybrid clones was strongly influenced by genetic factor and thus provided a potency to obtain better clones through selection (Harwood \& Williams 1991). Similar result was also reported in other study using natural acacia hybrid clonal test at Song May and $\mathrm{Ba}$ Vi in Vietnam (Kha 2001).

In present study, 12 of 44 tested clones outperformed in height growth compared to the growth of trees in original population of pure $A$. mangium first-generation SSO (control 4), with superiority ranging between $1.8-35.4 \%$ (Table 5). The best 3 acacia hybrid clones: clone 44, 16, and 25 showed outstanding height growth compared to the control of superior pure species parents (control 1, 2, and 3) with superiority ranging between $3.51-17.28 \%$. The superiority of acacia hybrid to their pure species parents was also reported in clonal test of natural acacia hybrid in Vietnam at 2.5 years old (Kha 2001). The superiority of hybrid clone from other species has been also reported, such as hybrid of E. tereticornis $\times E$. camaldulensis clones in India (Quaile 1988), hybrid of E. pellita $\times E$. urophylla at Zimbabwe (Gwaze et al. 2000), and hybrid of E. urophylla $\times$ E. grandis at Kalimantan (Hardiyanto \& Tridasa 2000) and also E.grandis x E. camalulensis in Coastal Kenya (Kirongo et al. 2010).

Estimates of clone and individual repeatability in present study of acacia hybrid clonal test were high at 0.96 and 0.59 respectively. It indicated that selected clones could be potentially propagated with similar genetic quality. High clone repeatability was also reported on other species study, such as 2 years of E. grandis clone in Portugal with clone repeatability ranging between 0.87-0.91 (Boralho et al. 1992), and 3 years of E. camadulensis clone in Vietnam with clonal repeatibility ranging between $0.72-0.88$ (Kien 2009).

Based on the growth projection, the best acacia hybrid clone obtained from present study could potentially increase the stand productivity at around $17 \%$ over the best superior pure $A$. mangium derived from second-generation SSO of best provenance (Oriomo, Papua New Guinea). The stand productivity of the best selected acacia hybrid clone could be estimated at around $48 \mathrm{~m}^{3} \mathrm{ha}^{-1} \mathrm{y}^{-1}$. While the corresponding of current best productivity of pure A. mangium was at $41 \mathrm{~m}^{3} \mathrm{ha}^{-1}$ $\mathrm{y}^{-1}$ (Hastanto 2009). Study reported on other species revealed that the uses of clone of Prunus avium had increased the stand productivity Czechnya (Hajnala et al. 2007).

\section{Conclusion}

The results of study showed that series of research for developing breeding strategy of acacia hybrid has been achieved. Flowering time synchronization between $A$. mangium and $A$. auriculiformis provided probability for practicing of controlled pollination hybridization which could produce hybrid seeds with viability of $48.1 \%$. Leaves development pattern at seedling stage revealed to be an effective way to identify the acacia hybrid with accuracy of $92.2 \%$ after verifying using molecular marker. The selected acacia hybrid seedling were succesfully propagated using shoot cutting with rooting ability of $78.1 \%$. The result of field clonal test showed that the best 3 clones of acacia hybrid outperformed in height growth as compared to superior pure species of parents with the superiority ranging between $3.51-17.28 \%$. The stand productivity of the best selected acacia hybrid clone could be estimated at around 48 $\mathrm{m}^{3} \mathrm{ha}^{-1} \mathrm{y}^{-1}$. The results from a series of research showed that an effective and efficient breeding strategy for acacia hybrid (A. mangium $\times$ A . auriculiformis) has been well developed in providing superior acacia hybrid to increace forest plantation productivity.

\section{Acknowledgements}

We would like to express our gratitude to The Acacia and Eucalyptus team who have been involved in the establishment, maintenance and measuring the plot. We also acknowledge the contribution of Molecular Laboratory team at CFBTI.

\section{References}

Borralho NMG, Almeida IM, Cotterill PP. 1992. Genetic control of young Eucalyptus globulus clone in Portugal. Silvae Genetica 41(2):70-77.

Chaudary RC. 1984. Introduction to Plant Breeding. New Delhi. Bombay. Calcuta: Oxford \& IBH Publishing Co.

Falconer DS. 1989. Introduction to Quantitative Genetics. Longman Scientific \& Technical. New York: John Wiley and Sons. Inc.

Gan E, Sim BL. 1991. Nursery identification of hybrid seedlings in open plots. In: Carron LT, Aken KM, editors. Breeding Technologies for Tropical Acacias. Proceeding ACIAR. No. 37. Canberra. pp.76-85.

Gwaze DP, Bridgwater FE, Lowe WJ. 2000. Performance of interspesific F-1 Eucalypt hybrids in Zimbabwe. Forest Genetic (4): 295-303.

Hajnala M, Lstiburek M, Kobliha J. 2007. First evaluation of growth parameters in clonal test with wild cherry. Journal of Forest Science 53(2): 57-65.

Hardiyanto EB. 2004. Silvikultur dan pemuliaan $A$. mangium. In: Hardiyanto EB, Arisman $\mathrm{H}$, editors. Pembangunan Hutan Tanaman Industri. Pengalaman di PT. Musi Hutan Persada, Sumatera Selatan. 
Indonesian. Polydor. Yogyakarta. pp. 207-268.

Hardiyanto EB, Tridasa AM. 2000. Early performance Eucalyptus urophylla $\times$ E. grandis hybrid on several sites in Indonesia. In: Dungey HS, Dieters MJ, Nikles DG, editor. Hybrid Breeding and Genetics of Forest Trees. Proceeding of QFRI/CRC-SPF Symposium. Australia. pp 273-279.

Harwood CE, Williams CE. 1991. A review of provenance variation in growth of Acacia mangium. In: Carron LT, Aken KM, editors. Breeding Technologies for Tropical Acacias. Proceeding ACIAR. No. 37. Canberra. pp. 2230 .

Hastanto H. 2009. Peran benih unggul untuk meningkatkan produktivitas hutan tanaman Acacia mangium di PT. Musi Hutan Persada. In: Leksono B, Widyatmoko AYPBC, Nirsatmanto A, editors. Prosiding Ekspose Hasil-Hasil Penelitian BBPBPTH. Indonesian. Yogyakarta 1 Oktober 2009. pp.136-146.

Ibrahim Z. 1993. Reproductive Biology. In: Awang K, Taylor D, editors. Acacia mangium Growing and Utilization. Winrock International and the Food and Agriculture Organization of the United Nations. Bangkok. Thailand. pp 21-30.

Kato K, Yamaguchi S, Chigira O, Ogawa Y, Isoda K. 2012. Tube pollination using stored pollen for creating Acacia auriculiformis hybrid. Journal of Tropical Forest Science 24(2): 209-216.

Kha LD. 2000. Studies on natural hybrid of $A$. mangium and $A$. auriculiformis in Vietnam. Journal of Tropical Forest Science 12(4): 794-803.

Kha LD. 2001. Studies on the Use of Natural Hybrids between Acacia mangium and Acacia auriculiformis in Vietnam. Hanoi: Agriculture Publising House.

Kha LD, Harwood CE, Kien ND. 2012. Growth and wood basic density of acacia hybrid clones at three location in Vietnam. New Forest 43:13-29. http://dx.doi.org/10. 1007/s11056-011-9263-y.

Khalid I, Wahap R, Sulaiman O, Mohamed A, Tabet T, Alamjuri RH. 2010. Enhancing colour appearances of 15 cultivated 15 year old acacia hybrid through heat treatment process. International Journal of Biology 2(2):199-209.

Kien ND. 2009. Improvement of Eucalyptus plantation grown pulp production [Dissertation]. Uppala: Swedish University of Agricultural Sciences.

Kirongo BB, Kimani, Senelwa K, Etiegeni L, Mbelase A, Muchiri M. 2010. Five year growth and survival of eucalyptus hybrid clones in Coastal Kenya. Jurnal Manajemen Hutan Tropika 16(1):1-9.
Kim NT, Matsumura J, Oda K. 2009. Posibillity of inprovement in fundamental properties of wood of acacia hybrids by artificial hybridization. Journal Wood Science 55: 8-12. http://dx.doi.org/10.1007/s10086008-0993-1.

Monteuuis O. 1995. In vivo grafting and invivo micro grafting on Acacia mangium: Impact of orthet age. Silvae Genetica 44(4): 190-193.

Nghiem QC. 2012. Effect of ploidy level on the reproductive biology tropical acacia species [dissertation]. Australia: University of Tasmania.

Nikles DG, Hardwood, CE, Robson, KJ, Pomroy PC and Keenan RJ. 1998. Management and use of ex situ genetic resources of some tropical Acacias species in Queensland. In: Turnbull JW, Cropton HR, Pinyopusarerk K, editors. Developments in Acacias planting. ACIAR Proceedings. No. 82: Canberra, Australia.

Opik H, Rolfe S. 2005. The physiology of flowering plants. Cambridge University Press. Cambridge. http://dx.doi. org/10.1017/CBO9781139164450.

Pallardy SG. 2008. Physiology of woody plants. United State of America: Elsevier.

Paupard C, Chauviers M, Monteuuis O. 1994. Rooting Acacia mangium cutting: effect of age whitin shoot position and auxin treatment. Silvae Genetica 43(4): 226-230.

Rokeya UK, Hossain MA, Ali MR, Paul SP. 2010. Physical and mechanical properties of (Acacia auriculiformis $\times$ A. mangium) hybrid acacia. Journal of Bangladesh Academy of Sciences 32(2): 181-187.

Rufelds CW. 1988. Acacia mangium and Acacia auriculiformis and hybrid $A$. mangium $\mathrm{x} A$. auriculiformis seedling morphology study. Forest Research Center Publication (41): 53-63.

Sedgley M, Harbard J, Smith RM, Wickneswari R. 1991. Development of hybridization techniques for Acacia mangium and Acacia auriculiformis. In: Carron LT, Aken KM, editors. Breeding Technologies for Tropical Acacias. Proceeding ACIAR. No. 37. Canberra. pp 6369.

Sunarti S. 2007. Identifikasi Benih dan Semai Hibrid Acacia mangium $\times$ Acacia auriculiformis, Acacia auriculiformis $\times$ Acacia mangium Menggunakan Penanda Morfologi dan Penanda Molekuler SCAR. Yogyakarta: Graduate School Gadjah Mada University.

Sunarti S. 2011. Perbanyakan pada acacia hibrid ( $A$. mangium $\times A$. auriculiformis) dengan metode stek pucuk. Informasi Teknis 9(2): 1-6. 
from young seedlings. In: Carron LT, Aken KM, editors. Breeding Technologies for Tropical Acacias. Proceeding ACIAR. No. 37. Canberra. Australia. pp.112-115.

Widyatmoko AYPBC, Shiraishi S. 2003. Species-spesific RAPD marker for identification of Acacia mangium, $A$. auriculiformis and their hybrid. Kyushu Journal Forest Resources. Number: 56.

Wong CY, Haines RJ. 1991. Multiplication of families of Acacia mangium and Acacia auriculiformis by cutting
Yahya R, Sugiyama J, Gril J. 2010. Some anatomical features of acacia hybrid, A. mangium and $A$. auriculiformis grown in Indonesia with regard to pulp yield and strength paper. Journal of Tropical Forest Science 33(3): 343-351. 